\title{
The Implementation Of Borrowing Money Agreement With The Guarantee Of Movement Object In PT. Pegadaian (Persero) Branch Of Subang Based On Act No. 42 Of 1999 On Fiduciary
}

\begin{abstract}
Erwin Marlina ${ }^{1}$ and Akhmad Khisni ${ }^{2}$
Abstract. The purpose of this research is to know and understand the implementation of the agreement to borrow against moving objects Pegadaian of Subang district connected by Act No. 42 of 1999 on Fiduciary, and the constraints faced by Pegadaian of Subang district in the implementation of the agreement to borrow money secured against moving objects associated with Act No. 42 Of 1999 regarding Fiduciary, and solutions. Based on the results of data analysis can be concluded that: First,Implementation of the Money Lending and Borrowing Agreement with the guarantee of Moving Bodies PT. Pegadaian (Persero) is not in accordance with the provisions of Article 1320 and Article 1338 of the Civil Code, as the substance of the agreement is determined unilaterally by PT. Pegadaian (Persero) and very burdensome customers, whereall costs related to the disbursement of the loan and the auction process is borne by the customer, including if the customer requires registration, fiduciary, but most refused to register fiduciary because of the extra charge (additional costs to be borne by the customer and the need for immediate disbursement of credit requires a long time. this is contrary to Act No. 42 Of 1999 regarding Fiduciary. Secondly, the constraint faced by PT. Pegadaian (Persero) Branch of Subang in the Implementation Agreement with Collateral Borrowing Money on Moving objects are need customers defaulting party (broken promises). One type of breach committed by the debtor PT. Pegadaian (Persero) Branch of Subang is overdue, the delay in the implementation of the payment obligations on time specified in the agreement lending and borrowing. Solution by PT. Pegadaian (Persero) Branch of Subang is doingpersuasive efforts, Somasi (warning), withdrawal and auction the collateral in accordance with Act No. 42 of 1999 on Fiduciary.

Keywords: Implementation Agreement; Moving Objects Guarantee; PT Pegadaian.
\end{abstract}

\section{Introduction}

Indonesia's current state is in full swing implement national development in order to realize a just and prosperous society based on Pancasila and the Constitution of 1945. In the continued development of both the government and the community, both individuals and legal entities, would require huge funds. In addition, people's lives were not in spite of the variety of needs and to meet these needs are limited, so in an effort to meet the needs of the funds needed. These funds may come from wealth itself and from loans sourced from both financial institutions and non-bank financial institution bank. Financial institutions are expected to provide credit on terms that do not burden the public and assurance to the public light, business. ${ }^{3}$

One credit is run now by PT. Pegadaian (Persero) Branch of Subang is a credit agreement with fiduciary known as Creative services (Installment Loans Fiduciary). The

1 Students of Master of Notary Law Faculty of Law UNISSULA Semarang email: erwinmarliana99@gmail.com

${ }^{2}$ Lecturer in Faculty of Law UNISSULA Semarang

${ }^{3}$ Rachmadi Usman 2001 Aspek-aspek Hukum Perbankan di Indonesia Gramedia Pustaka Utama Jakarta p. 156. 
policy was taken in order to adapt the development of business and the needs of an increasingly complex society. Fiduciary insurance is one form of security that arises to supplement deficiencies in pawn. Customer PT. Pegadaian consists of the economically disadvantaged underserved from a financial institution or bank, so that the lower middle income people need a loan easily and quickly.

Credit services with fiduciary was formed in order to guarantee goods can still be used by the debtor in order to support its business although it has been used as the object of a guarantee. PT. Pegadaian (Persero) Branch of Subang in lending / credit applies the fiduciary to meet the needs of people in the world, so that borrowers with fiduciary guarantee could be given a loan without collateral to the lenders deliver the goods. Because, In a fiduciary agreement, the authority of the master objects, which referred to the delegation of authority to control objects assurance, but this needs to be underlined the authority of mastering not be the same as the will of the master, because the will to master a part which is prohibited in the fiduciary agreement, delegation of authority over a part of responsibility given to the recipient of fiduciary fiduciary giver to complete the loan by selling the collateral objects.

Giving credit to the fiduciary there are two parties involved, the creditor as the party receiving the fiduciary-called "fiduciary holder" and the debtor as a party that offers goods is called "fiduciary giver". Every credit must be accompanied by a guarantee for safety measuren credit extended. Debtor surrender fiduciary objects as security for repayment of debts to creditors in the event of a credit agreement. An important guarantee in order to maintain security and provide legal certainty for creditors to get back or get a refund of certainty regarding the loan has been granted by the creditor to the debtor in accordance with a predetermined and agreed upon. Goods which become the fiduciary objects are not submitted by the debtor (the public) to the lenders (pawn shops), so that the goods were pledged under the authority of the debtor. ${ }^{4}$

Based on the background pointed out above, the writer interested to further evaluate the results of which will be poured into the form of research under the title: " Implementation of Borrowing Money Agreement With The Guarantee of Movement Object In PT. Pegadaian (Persero) Branch of Subang Based On Act No. 42 of 1999 On Fiduciary".

\section{Research methods}

The research method used in this research is descriptive analyst, with normative juridical approach. The research was conducted by means of research literature and field research techniques of collecting data through documentation study and interviews and data analysis method which used in this research by using qualitative juridical analysis.

\section{Results And Discussion}

\subsection{Implementation of Borrowing Money Agreement With The Guarantee of Movement Object In PT. Pegadaian (Persero) Branch of Subang Based On Act No. 42 of 1999 On Fiduciary}

\footnotetext{
${ }^{4}$ Gunawan Widjaja dan Ahmad Yani 2003 Jaminan Fidusia Raja Grafindo Persada Jakarta p. 28.
} 
Agreement to borrow money in accordance with Chapter XIII of the Civil Code Book III has a real nature. This means that this agreement only after a handover. During the object (money) the agreement has not been submitted, it has not said a loan agreement pursuant to Chapter XIII of the Civil Code. In this case, Mariam Darus Badrulzaman states: "The loan agreement money under Chapter XIII of the Civil Code is to be real, if seen from the content of Article 1754 of the Civil Code, namely the word" give ". If the two parties have agreed on all elements in the loan agreement to replace, it does not mean that the agreement on the loan to replace it has happened. That happened only an agreement to hold new loan agreements. If the money is handed over to the borrower's loan agreement was signed to replace in terms of legislation under Chapter XIII of the Civil Code ". ${ }^{5}$

Thus, the agreement to borrow money is real, is summed up from the phrase "unity party handed over the money to the other party" and not "lead themselves to hand over the money".

Lending agreement entered into between the PT. Pegadaian (Persero) and the Customer must fulfill the terms of the validity of the agreement, as contained in Article 1320 of the Civil Code. The reaction is one of them is the current economic slowdown, which would need a high capital not followed by providing sufficient capital, so that in the framework of the capital efficiency of the loan is only limited to the purchase of the means of production that does not exist, whereas the means of production are now no longer need to be refurbished but still used at once as part of the collateral for the loan debt for a business, the concept is a reaction to the inefficiency of the security agreement a pledge that has been known in practice, where the object guarantee must be in the control of the pawn, thereby inhibiting conditions for the business world, then made fiduciary agreement. In contract law apply a principle called the principle of consensualism, the word "consensualism" is derived from the Latin word which means unanimous consensus. Consensualism principle is not meant for an agreement required the agreement, it should be. An agreement also called agreement, it means that the two parties have agreed or agree on something. In this case R.Subekti states: "The agreement means that the conformity of the will but the will or desire to be expressed. Will or desire that is stored in the liver may not be known to the other party and therefore not likely to deliver agreed needed to give birth to an agreement ". 6

They agreed on terms that bind himself, described by Mariam Darus Badrulzaman which states: "With the need for an agreement entered into an agreement, then it means that both parties must have the freedom of the will. The parties do not gain anything pressure resulting in their "disability" for the realization of the will. Understanding agreed depicted as a statement of the will of the approved (overeenstemende wilsverklaring) between the parties. The statement called the parties offering bid (offerte). The statement called the parties to accept the offer acceptances (acceptatie). "7

In any treaty must be agreed by the parties certainly related to the terms of lending money (credit), the substance of the agreement and agreement procedure. Some of the things that became Substance borrowing agreement with fiduciary money that must be agreed by the customer with PT. Pegadaian (Persero) Branch of Subang is as follows: ${ }^{8}$

\footnotetext{
5 Mariam Darus Badrulzaman 1983 Perjanjian Kredit Bank Alumni Bandung p. 26.

${ }^{6}$ R.Subekti 2001 Hukum Perjanjian Intermasa Jakarta p. 6.

7 Mariam Darus Badrulzaman op.cit. p. 98.

8 Ibid.
} 
- Customer accepts and agrees to the description of Goods Guarantees, Determination of magnitude estimates of Goods Guarantee, Money Loans, Rental Rate of Capital and Administrative Costs as stipulated in the letter Proof of Credit (SBK) or Memorandum of Transactions (receipts) and as proof of a valid receipt of money lending.

- Customers can re-pawn, pawn Autoremarketing, ask for more Money Loans, and delay the auction, as long as they qualify the value estimated by calculating the Capital Lease and Administrative Costs which are still to be paid. If a decline in Item Estimated Value Assurance at the time of re Pawn or Pledge Autoremarketing, the customer shall be allowed to pay the loan or guarantee product manambah to fit the new estimates.

- Against the collateral that has been settled and has not been taken by the customer, starting from the date of repayment of up to ten days is not subject to daycare. When it has exceeded ten days of repayment, collateral still has not been taken by the customer, the customer agreed imposed Care Services, Magnitude Care Services in accordance with the applicable provisions in PT. Pegadaian (Persero) or contained in the net of transaction (receipt).

- The results of the auction sale of the collateral after deducting Money Loans, Capital Lease, Auction Process Costs (if any) and the Customs Auctions, an excess of the right customers. Duration making excess money auction for one year from the date of the auction and if the expiration of a period of excess money withdrawal, the customer agreed to distribute the excess cash as a fund of social concern that its implementation be submitted to PT. Pegadaian (Persero). If the results of the auction sale of the collateral is insufficient to repay the loan obligations are customers in the form of money, Lease Capital Cost auction process (if any) and customs auction, the customer shall pay the shortfall.

- Customer states that are subject to and comply with the regulations in PT. Pegadaian (Persero) insofar as the provision concerning debts with collateral pledge ".

There are several things that must be considered in the implementation of the agreement customers borrowing money with fiduciary PT. Pegadaian (Persero) Branch of Subang, as follows:

- Capital lease rate per 15 days, for 1 day to 15 days calculated equal to 15 days.

- Capital lease amounting to $1.15 \%$ / 15 days

- Capital leases is calculated from the date of the credit until the final settlement date, the result is rounded up to a multiple of Rp. 100.

- The maximum credit period of 120 days. Loans can be repaid or renewed (remortgage, repay the loan money, and ask for more money loan) until the maturity date.

- If repeated pledge / extended. The collateral liens must be paid in installments as follows:

- Electronic / Gadgets at $20 \%$ of the loan money

- Another warehouse goods amounting to $5 \%$ of the loan money

- Vehicles at $10 \%$ of the loan money

- When the transaction settlement and credit renewal is done by the customer at the branch / unit online pawn shop or other place designated by PT. Pegadaian (Persero), the customer has approved the memorandum of transactions (receipts) as amended agreement and Proof of this credit.

- To the renewal of credit to the maturity date, the date of the auction and the amount of money stated in the memorandum loan transaction (receipt). 
- Auction postponement request can be serviced prior to maturity by filling out the form arrives been provided. Delays auction charged according to applicable regulations at the Pegadaian.

- Capturing the collateral must submit a Proof of original credit and identity cards (KTP / SIM).

- Proof of credit and transaction memorandum (strruk) must be stored properly, if missing should report to Branch / Unit Pawn issuer credit Proof

- If the loan is not repaid or extended until the date of maturity, the collateral will be auctioned with the following conditions:

- Auction process costs by $0.5 \%$ per 15 days

- Auction fees of $2.0 \% \times$ the price of collaterals

- Security items in Auction Process (BJDPL) can be completed by the customer with an additional cost of settlement administration BJDPL $0.75 \%$ / 15 days of the loan money and a maximum of $2.25 \%$ of the loan money ".

The procedures for implementation lending (credit) with fiduciary PT. Pegadaian (Persero) Branch of Subang is as follows: ${ }^{9}$

- A copy of the submission of the Identity and Collateral Customers come to the window of a Pegadaian to submit a copy of identity card (KTP / SIM / Passport) and the collateral to be pledged.

- Rating Collateral Pegadaian clerk handed assess customer collateral in order to determine the value and the amount of loans that can be obtained.

- Credit Approvol

- Confirmation to the customer for approval of the loan amount.

- Approvol by Pegadaians internal process in stages according to the amount of loan money.

- Administration of Credit Agreement

Pegadaian clerk processing credit agreement (Proof of Credit).

- $\quad$ Signing of Credit Agreement (Proof of Credit)

Pegadaian clerk and the customer sign the Proof of Pledge (SBG) SBG First brought customers and a copy kept Pawnshop.

- Credit disbursement

Customers receive the loan money amount has used, submitted by the Pegadaian clerk ".

The results showed that the rights and obligations of both parties in the agreement borrowing money (credit) at PT. Pegadaian (Persero) Branch of Subang is as follows:

- Rights of PT. Pegadaian (Persero) Branch of Subang

- Take actions that may be necessary if the customer is considered a promise or proven negligent injury (Article 7, paragraph 1 and 2);

- Execution of client collateral, negligent or if the customer would not be able to meet the requirements and obligations under this agreement. (Article 9, paragraph 1-4);

- Liabilities PT. Pegadaian (Persero)

- Provide the maximum amount of credit, purpose and loan period. (Article 1, paragraph $1,2,3$ ).

- Providing capital leases and fees incurred in this agreement. (Article 2, paragraph 1 and 4).

\footnotetext{
${ }^{9}$ Results of interviews with Deni Munandar as Credit Analysis PT. Pegadaian (Persero) Branch of Subang on April 17 at 13:00 pm.
} 
- Doing delivery of replacement goods to the customer guarantee in case of force majeure (Article 8).

- $\quad$ Customer rights

Receive the maximum amount of credit, and credit term objectives (Article 1, paragraph 1-3).

- Customer obligations

- Pay a capital lease and other costs incurred in this agreement (Article 2, paragraph 1-4).

- Submit items that made the object of a guarantee (Article 3, paragraph 1-6).

- Perform maintenance of customer collateral (Article 4, paragraph 1).

- Make payments for credit repayment (Article 5, paragraph 1-7).

- Pay penalties for late payment of installments (Article 6, paragraph 1-6).

- Doing delivery of replacement goods to the customer guarantee in case of force majeure (Article 8).

- When it has exceeded ten days of repayment, collateral still has not been taken by the customer, the customer shall pay Care Services, Magnitude Care Services in accordance with the applicable provisions in PT. Pegadaian (Persero) or contained in the net of transaction (receipt) (Article 10, paragraph 1-4).

- Customer must know and comply with the credit agreement's validity period (Article 11, paragraph 1-5).

- If the results of the auction sale of the collateral is insufficient to satisfy the obligations of the customer in the form of money lending, Lease Capital Cost auction process (if any) and customs auction, the customer shall pay the shortfall(Article 12).

"The goods can be accepted as collateral in PT. Pegadaian (Persero) is as follows:

- Household goods, such as household furniture, pottery, and electronic equipment;

- Tractors, water pumps, generators and chainsaws (chainsaw);

- Textiles such as fabrics, gloves, bed linen, and tapestry; and

- Other goods that have economic value that will be governed by the rules of Pegadaians. "

Furthermore, Faiz stated: ${ }^{10}$ "Things can not be accepted as collateral in PT. Pegadaian (Persero) is as follows:

- Government-owned items, such as firearms, weapons, uniforms, and equipment TNI / Polri

- Consignment goods;

- Goods that are perishable, such as food, beverages, and pharmaceuticals;

- Dangerous goods and flammable, such as lighters, fireworks (firecrackers), gunpowder, gasoline, kerosene, and gas-filled tube;

- Goods are banned, such as drugs (marijuana, opium, heroin, methamphetamine, and the like);

- Goods that are not fixed costs and is difficult to determine the estimate, such as paintings, books, antiquities and antiques;

- Other items such as apparel, goods that use is very limited and not common, for example, medical equipment, telecommunication equipment, and equipment of the party; and

- Animals / livestock. "

\footnotetext{
${ }^{10}$ Results of interviews with Faiz as Chairman of PT. Pegadaian (Persero) Branch of Subang on Monday April 17 at 09.00 am.
} 


\subsection{Faced Constraint by PT. Pegadaian (Persero) Branch of Subang in the Implementation Agreement Collateral Borrowing Money in Moving Objects based on Act No. 42 Of 1999 Regarding Fiduciary And Solutions}

In the implementation of installment credit facilities fiduciary system in PT. Pegadaian (Persero) Branch of Subang, most customers were able to run it with good credit with its obligations to make payments and repayment of loan installments when making the agreement. But there are also cases of customer delays in making installment payments and even some customers who are not able to pay off the loan installments. According Yudha Akbar states: "The obligation that is not often performed on the contents of the agreement customers during 2014 until December 2016 is to make a payment but has been delayed and the payment of arrears of as much as 3 times so do the execution. ${ }^{11}$

One type of breach committed by the debtor PT. Pegadaian (Persero) Branch of Subang is overdue. Understanding is a delay in the implementation of overdue payment obligations at the time specified in the agreement lending and borrowing. Late payments are classified into four categories as follows: ${ }^{12}$

- Overdue over 45 days but less than 60 days;

- Overdue over 60 days but under 90 days;

- Overdue over 90 days but below 150 days;

- Overdue over 150 days.

This overdue can be put into the category of tort be done but too late, in this case the debtor still going to pay the installment but after the payment due date has passed.

Default is not fulfilling or fails to perform the obligations as specified in the agreement made between the creditor and the debtor. ${ }^{13}$

\section{CLOSING}

\subsection{Conclusion}

Based on the research results can be concluded as follows:

- Implementation of the Money Lending and Borrowing Agreement with the guarantee of Moving Bodies PT. Pegadaian (Persero) is not in accordance with the provisions of Article 1320 and Article 1338 of the Civil Code, as the substance of the agreement is determined unilaterally by PT. Pegadaian (Persero) and very burdensome customers, whereall costs related to the disbursement of the loan and the auction process is borne by the customer, including if the customer requires registration, fiduciary, but most refused to register fiduciary because of the extra charge (additional costs to be borne by the customer and the need for immediate disbursement of credit requires a long time. this is contrary toAct No. 42 Of 1999 regarding Fiduciary.

- Constraint faced by PT. Pegadaian (Persero) Branch of Subang in the Implementation Agreement with Collateral Borrowing Money Moving objects are melukukan customers defaulting party (broken promises). One type of breach

\footnotetext{
${ }^{11}$ Yudha the interview with Akbar as Estimator at. PT. Pegadaian (Persero) Branch of Subang on April 18 at 10:00 am.

12 Results of interviews with Faiz as Chairman of PT. Pegadaian (Persero) Branch of Subang on April 172017 10:00 pm.

${ }^{13}$ Salim H.S. 2008 Hukum Kontrak Teori Dan Teknik Penyusunan Kontrak Sinar grafika Jakarta p. 98.
} 
committed by the debtor PT. Pegadaian (Persero) Branch of Subang is overdue, the delay in the implementation of the payment obligations on time specified in the agreement lending and borrowing. Solution by PT. Pegadaian (Persero) Branch of Subang is doingpersuasive efforts, Somasi (warning), withdrawal / Peyitaan Baran, and auction the collateral in accordance with Act No. 42 of 1999 on Fiduciary.

\subsection{Suggestion}

Based on the above conclusions, the researchers gave suggestions as follows:

- $\quad$ PT. Pegadaian (Persero) Branch of Subang in making arrangements with Fiduciary security should be made by notarial deed, do not need to be provisions nominal amount that is to determine the agreement which was made by a notary and agreements which are made by deed under the hand, even though the agreement made by deed under the hand may be requested certification to the notary. In addition, it is also more favorable to the PT. Pegadaian (Persero) Branch of Subang as the creditor (recipient of fiduciary) for creditor preference (right to precedence) of other creditors. On the other creditors also gained the authority to carry out execution if the debtor does not pay off the debt (default).

- In the Law of Fiduciary not specified a deadline for registering Fiduciary Fiduciary Registration Office, so it's often overlooked. Therefore, the obligation to register the treaty Fiduciary Fiduciary Registration Office in order to be considered, because the presence of Deeds Registration Fiduciary creditors become stronger position legally.

\section{Bibliography}

[1] Rachmadi Usman 2001 Aspek-aspek Hukum Perbankan di Indonesia Gramedia Pustaka Utama Jakarta.

[2] Gunawan Widjaja dan Ahmad Yani 2003 Jaminan Fidusia Raja Grafindo Persada Jakarta.

[3] Mariam Darus Badrulzaman Perjanjian Kredit Bank Alumni Bandung 1983.

[4] R.Subekti Hukum Perjanjian Intermasa Jakarta 2001.

[5] Yudha the interview with Akbar as Estimator at. Pawnshop (Persero) Branch Subang on April 18 at 10:00 am.

[6] Results of interviews with Faiz as Chairman of PT. Pawnshop (Persero) Branch Subang on April 172017 10:00 pm.

[7] Results of interviews with Deni Munandar as Credit Analysis PT. Pawnshop (Persero) Branch Subang on April 17 at 13:00 pm.

[8] Salin H.S. 2008 Hukum Kontrak Teori Dan Teknik Penyusunan Kontrak Sinar Grafika Jakarta.

[9] The Book Of The Civil Law (Civil Code)

[10] Act No. 42 of 1999 On The Fiduciary 